\title{
Angiotensin IV Receptors Mediate the Cognitive and Cerebrovascular Benefits of Losartan in a Mouse Model of Alzheimer's Disease
}

\author{
니 Jessika Royea, Luqing Zhang, Xin-Kang Tong, and Edith Hamel \\ Laboratory of Cerebrovascular Research, Montreal Neurological Institute, McGill University, Montréal, Quebec, Canada H3A 2B4
}

The use of angiotensin receptor blockers (ARBs) correlates with reduced onset and progression of Alzheimer's disease (AD). The mechanism depicting how ARBs such as losartan restore cerebrovascular and cognitive deficits in AD is unknown. Here, we propose a mechanism underlying losartan's benefits by selectively blocking the effects of angiotensin IV (AngIV) at its receptor (AT4R) with divalinal in mice overexpressing the AD-related Swedish and Indiana mutations of the human amyloid precursor protein (APP mice) and WT mice. Young (3-month-old) mice were treated with losartan $(\sim 10 \mathrm{mg} / \mathrm{kg} / \mathrm{d}, 4$ months), followed by intracerebroventricular administration of vehicle or divalinal in the final month of treatment. Spatial learning and memory were assessed using Morris water mazes at 3 and 4 months of losartan treatment. Cerebrovascular reactivity and whisker-evoked neurovascular coupling responses were measured at end point ( $\sim 7$ months of age), together with biomarkers related to neuronal and vascular oxidative stress (superoxide dismutase-2), neuroinflammation (astroglial and microglial activation), neurogenesis (BrdU-labeled newborn cells), and amyloidosis [soluble amyloid- $\beta(\mathrm{A} \beta)$ species and $\mathrm{A} \beta$ plaque load]. Divalinal countered losartan's capacity to rescue spatial learning and memory and blocked losartan's benefits on dilatory function and baseline nitric oxide bioavailability. Divalinal reverted losartan's anti-inflammatory effects, but failed to modify losartan-mediated reductions in oxidative stress. Neither losartan nor divalinal affected arterial blood pressure or significantly altered the amyloid pathology in APP mice. Our findings identify activation of the AngIV/AT4R cascade as the underlying mechanism in losartan's benefits and a target that could restore A $\beta$-related cognitive and cerebrovascular deficits in AD.

Key words: Alzheimer's disease; angiotensin IV receptors; cerebrovascular function; inflammation; memory; renin angiotensin system

Signifiance Statement

Antihypertensive medications that target the renin angiotensin system, such as angiotensin receptor blockers (ARBs), have been associated with lower incidence and progression of Alzheimer's disease (AD) in cohort studies. However, the manner by which ARBs mediate their beneficial effects is unknown. Here, the angiotensin IV receptor (AT4R) was identified as mediating the cognitive and cerebrovascular rescue of losartan, a commonly prescribed ARB, in a mouse model of AD. The AT4R was further implicated in mediating anti-inflammatory benefits. AT4R-mediated effects were independent from changes in blood pressure, amyloidosis, and oxidative stress. Overall, our results implicate the angiotensin IV/AT4R cascade as a promising candidate for AD intervention.

\section{Introduction}

Alzheimer's disease (AD) is characterized by progressive neuronal deficits, tau pathology, increases in amyloid- $\beta(\mathrm{A} \beta)$ peptides and $\mathrm{A} \beta$ plaque formation, oxidative stress, and glial cell activation (Hardy et al., 2002; McGeer et al., 2003). AD patients also display a cerebrovascular pathology characterized by blood- 
brain barrier disruption, microhemorrhages, and microvascular rarefaction, but most importantly by an early vascular dysregulation (Iturria-Medina et al., 2016). The latter incorporates deficits in resting cerebral blood flow (CBF), cerebrovascular reactivity, and neurovascular coupling, which result in reduced oxygen and nutrient delivery to the brain (Girouard et al., 2006; Gorelick et al., 2011; Serrano-Pozo et al., 2011).

The probability of developing $\mathrm{AD}$ increases with age and the presence of vascular risk factors. Particularly, midlife chronic hypertension, the main cardiovascular risk factor of sporadic $\mathrm{AD}$, increases the likelihood of developing mild cognitive impairment (Reitz et al., 2007) and the frequency of transitioning to AD compared with normotensive individuals (Khachaturian et al., 2006). Because hypertension is modifiable, its treatment represents an opportunity for AD prevention. Specifically, cohort studies have demonstrated lower incidence and progression to AD in elderly individuals treated with antihypertensive medications. These medications mainly target the renin angiotensin system (RAS), the body's main blood pressure regulation system, and include angiotensin-converting enzyme (ACE) inhibitors and angiotensin receptor blockers (ARBs) (Mogi et al., 2009; Villapol et al., 2015; Zhuang et al., 2016). Studies have highlighted the pleiotropic effects of these drugs intended to improve vascular function, but have not determined how ARBs can restore neuronal and cerebrovascular function (Takeda et al., 2009; Ongali et al., 2014; Villapol et al., 2015; Akioyamen et al., 2016).

The brain's RAS is independent from the peripheral RAS (Ganten et al., 1971) and contains every precursor and enzyme required for the synthesis of its main biologically active peptides, angiotensin II (AngII) and angiotensin IV (AngIV). Abnormalities in central RAS are present in AD patients and include upregulation of AngII and AngII type 1 receptors (AT1Rs), as well as decreased activity of ACEs (Savaskan et al., 2001; Kehoe et al., 2016). ARB treatment in various AD mouse models has prevented or rescued cerebrovascular, neuropathological, and cognitive deficits with or without affecting amyloidosis (Wang et al., 2007; Mogi et al., 2008; Takeda et al., 2009; Ongali et al., 2014). Moreover, ARB treatment has been suggested to result in an increase in the conversion of AngII to AngIV (Braszko et al., 2006). Interestingly, AngIV administration has been shown to improve memory performance (Braszko et al., 1988; Wright et al., 1999; Tchekalarova et al., 2001), enhance long-term potentiation (LTP) (Kramár et al., 2001; Wayner et al., 2001), and increase CBF (Kramár et al., 1997; Kramár et al., 1998). It is thus possible that AngIV mediates the cognitive and cerebrovascular benefits of chronic ARB administration through AngIV receptors (AT4Rs) (Shibasaki et al., 1999; Ongali et al., 2014).

Herein, we tested whether AT4Rs mediate losartan's cerebrovascular and cognitive rescue in a transgenic mouse model of AD. We administered losartan for 4 months and investigated the effects of concomitant divalinal delivery, an AT4R antagonist (Wright et al., 1999), in the last month of treatment while assessing spatial learning and memory, whisker-evoked neurovascular coupling, cerebrovascular reactivity, and anatomical and biochemical markers of target pathways. Our results demonstrate that blocking AT4Rs countered losartan's benefits on spatial learning and memory, cerebrovascular function, and inflammation. AT4R benefits were independent from arterial blood pressure, amyloidosis, and oxidative stress. Overall, these findings identify the AngIV/AT4R cascade as a highly promising new target for recovery of both cognitive and cerebrovascular dysfunctions in $\mathrm{AD}$.

\section{Materials and Methods}

Mouse model

Heterozygous transgenic C57BL/6 mice expressing the human amyloid precursor protein (APP) carrying the Swedish (K670N, M671L) and Indiana (V717F) familial AD mutations directed by the platelet-derived growth factor (PDGF) $\beta$-chain promoter (APP mice, J20 line) (Mucke et al., 2000) and WT littermate mice were used in approximately equal gender proportions. All experiments were in compliance with the Animal Ethics Committee of the Montreal Neurological Institute (McGill University, Montréal, Quebec, Canada) and met all guidelines of the local and national Canadian Council of Animal Care.

\section{Treatments}

Two independent cohorts of mice were randomly allocated to receive losartan ( $\sim 10 \mathrm{mg} / \mathrm{kg}$ of body weight/d; Cedarlane), an AT1R antagonist, in their drinking water or the same drinking water without treatment (Ongali et al., 2014). Losartan administration began at 3 months of age and continued for 4 months (cohort $1: n=28 \mathrm{WT}, n=32 \mathrm{APP}$; cohort 2: $n=34 \mathrm{WT}, n=34 \mathrm{APP}$ ). After the first Morris water maze (MWM1), losartan-treated mice were separated into two equally performing groups based on their probe performance and swimming speed. Losartan-treated mice were surgically implanted with subcutaneous osmotic mini-pumps (2.64 $\mu \mathrm{l}$ delivery/d; Alzet) connected to an intracerebroventricular catheter positioned within the right ventricle that delivered either the AT4R blocker divalinal ( $24 \mathrm{nmol} / \mathrm{d}$; Auspep, cohort 1: $n=11 \mathrm{WT}$ and $n=14$ APP; cohort 2: $n=17$ WT and $n=17$ APP (Krebs et al., 1996; Wright et al., 1999) or vehicle (artificial CSF, cohort $1: n=10 \mathrm{WT}$ and $n=10 \mathrm{APP}$, cohort 2: $n=17$ WT and $n=17$ ) during the final month of treatment. In the final $10 \mathrm{~d}$ of treatment, BrdU ( $\sim 1 \mathrm{mg} /$ mouse/d; Sigma-Aldrich) was added to the drinking water (Magavi et al., 2000) (supplemented or not with losartan) for subsequent investigations of neurogenesis (see below). Treatments did not affect mouse survival rates throughout the experiment.

\section{Blood pressure measurement}

Blood pressure was measured monthly in cohort 2 by noninvasive tailcuff plethysmography (Kent Scientific) as described previously (Duchemin et al., 2013). Body temperature was monitored and maintained at $37^{\circ} \mathrm{C}$ by a heating table. Mice were restrained and underwent 10 acclimation cycles followed by 10 experimental measurements. No change was observed in either systolic or diastolic blood pressure across genotype and treatment conditions (Table 1).

\section{MWM}

For both cohorts, MWM1 was performed after 3 months of losartan treatment and consisted of a $3 \mathrm{~d}$ familiarization period $(1.4 \mathrm{~m}$ diameter pool filled with opaque water at $17 \pm 1^{\circ} \mathrm{C}$ ) during which mice were given 3 daily trials $(60 \mathrm{~s} /$ trial, $45 \mathrm{~min}$ intertrial interval) to reach a visible platform (15 cm diameter, $1 \mathrm{~cm}$ above the water surface) located in the southeast quadrant of the pool in a room comprising distal visuospatial cues on the surrounding walls (Deipolyi et al., 2008). Subsequently, visuospatial cues and platform location were switched and $5 \mathrm{~d}$ of consecutive learning commenced. Mice were given 3 daily trials ( $90 \mathrm{~s} / \mathrm{trial}, 45 \mathrm{~min}$ intertrial interval) to locate the submerged platform $(1 \mathrm{~cm}$ below the water surface, located in the northwest quadrant of the pool). On day 9 , a probe trial ( $60 \mathrm{~s}$, platform removed) was conducted to observe whether mice recalled the location of the hidden platform.

After 3 weeks of concomitant losartan and divalinal or vehicle administration, a second MWM (MWM2) was initiated and consisted of $5 \mathrm{~d}$ of hidden platform testing. Mice were given 3 daily trials ( $90 \mathrm{~s} / \mathrm{trial}, 45 \mathrm{~min}$ intertrial interval) to reach the hidden platform located in the southwest quadrant using repositioned visuospatial cues. On day 6, mice underwent a probe trial $(60 \mathrm{~s}$, platform removed, performed at 1 month of divalinal treatment). For both MWMs, parameters were recorded using the 2020 Plus tracking system and Water 2020 software (Ganz FC62D video camera; HVS Image). In cohort 1 , mice $(n=6)$ unable to reach the visible platform on day 3 of MWM1 were excluded. All experiments began at the same time daily. 
Table 1. Effects of losartan and divalinal on blood pressure in WT and APP mice

\begin{tabular}{|c|c|c|c|c|c|c|}
\hline Week & WT & WT-L & WT-LD & APP & APP-L & APP-LD \\
\hline \multicolumn{7}{|c|}{ Systolic blood pressure $(\mathrm{mmHg})$} \\
\hline 4 & $133.85 \pm 2.78$ & $131.72 \pm 2.42$ & $134.02 \pm 3.44$ & $136.47 \pm 2.45$ & $137.86 \pm 3.46$ & $130.08 \pm 5.03$ \\
\hline 8 & $119.37 \pm 3.05$ & $127.35 \pm 1.30$ & $125.32 \pm 2.36$ & $126.36 \pm 4.26$ & $122.96 \pm 1.93$ & $121.53 \pm 5.62$ \\
\hline 12 & $126.10 \pm 0.53$ & $128.84 \pm 3.56$ & $119.15 \pm 3.80$ & $121.65 \pm 3.35$ & $121.05 \pm 4.72$ & $120.96 \pm 5.52$ \\
\hline 16 & $124.35 \pm 2.87$ & $123.19 \pm 1.20$ & $131.85 \pm 3.64$ & $123.25 \pm 2.80$ & $130.40 \pm 4.45$ & $125.56 \pm 1.58$ \\
\hline \multicolumn{7}{|c|}{ Diastolic blood pressure (mmHg) } \\
\hline 4 & $105.33 \pm 3.17$ & $102.74 \pm 2.29$ & $102.74 \pm 1.16$ & $108.21 \pm 3.37$ & $107.2 \pm 5.22$ & $101.33 \pm 6.15$ \\
\hline 8 & $93.33 \pm 2.27$ & $101.05 \pm 2.39$ & $99.12 \pm 3.05$ & $102.24 \pm 3.07$ & $101.08 \pm 2.82$ & $99.00 \pm 5.30$ \\
\hline 12 & $101.70 \pm 1.29$ & $103.66 \pm 3.62$ & $90.09 \pm 3.38$ & $96.10 \pm 2.56$ & $97.70 \pm 4.49$ & $96.48 \pm 5.11$ \\
\hline 16 & $101.20 \pm 2.33$ & $99.15 \pm 3.14$ & $105.60 \pm 5.10$ & $99.20 \pm 2.88$ & $106.95 \pm 5.36$ & $100.48 \pm 2.46$ \\
\hline
\end{tabular}

Data are represented as the mean $\pm \operatorname{SEM}(n=5-6$ mice per group) and are expressed as the systolic and diastolic blood pressure measurements obtained using tail-cuff plethysmography. The week of measurement is indicated with respect to the start of losartan treatment. Two-way ANOVAs followed by Newman-Keuls post hoc multiple-comparisons test revealed no significant differences in systolic or diastolic blood pressure measurements across genotype and treatment conditions. L, Losartan; D, divalinal.

Laser Doppler flowmetry (LDF)

After MWM2, mice from both cohorts ( $n=5-6$ /group) were used for LDF (Transonic Systems) experiments to measure the increase in CBF evoked by whisker stimulation, as described previously (Tong et al., 2009). Mice were anesthetized with a mixture of ketamine $(85 \mathrm{mg} / \mathrm{kg}$, i.m.; Bioniche) and xylazine ( $15 \mathrm{mg} / \mathrm{kg}$, i.m.; Haver), positioned in a stereotaxic frame, and the bone over the left barrel cortex (coordinate: 0-1 mm posterior, 3.5-4.5 mm lateral from bregma; Ayata et al., 2004) was thinned to translucency. Body temperature was monitored and maintained at $37^{\circ} \mathrm{C}$ with a heating blanket. Four to five CBF measurements were recorded before, during, and after contralateral (right snout) whisker stimulation $(20 \mathrm{~s}, 8-10 \mathrm{~Hz}, 30-40 \mathrm{~s}$ intervals). The probe was repositioned until the location with the highest CBF increase was identified and reliably reproduced after repeated stimulations. The change in $\mathrm{CBF}$ was expressed as the percentage increase relative to prestimulus baseline.

\section{Tissue preparation}

For each cohort, a subgroup of mice ( $n=4-6$ /group) were decapitated, their brains rapidly extracted, and posterior cerebral arteries (PCAs) were isolated for immediate measurements of cerebrovascular reactivity (see below). Remaining pial vessels were extracted together with the cerebral cortex and hippocampus, frozen on dry ice, and kept at $-80^{\circ} \mathrm{C}$ for subsequent protein analysis (see below). A second subgroup ( $n=5 \mathrm{mice} /$ group from each cohort) was anesthetized $(65 \mathrm{mg} / \mathrm{kg}$ of sodium pentobarbital, i.p.) and perfused intracardially using $4 \%$ paraformaldehyde (PFA) in cold PBS $(0.1 \mathrm{M}, \mathrm{pH} 7.4)$. The brains were postfixed (4\% PFA, overnight), cryoprotected ( $48 \mathrm{~h}$ in $30 \%$ sucrose, $\left.4^{\circ} \mathrm{C}\right)$, frozen in isopentane $\left(-40^{\circ} \mathrm{C}\right)$, and sectioned coronally using a freezing microtome $(25-$ $\mu \mathrm{m}$-thick sections for the left hemisphere and $40-\mu \mathrm{m}$-thick sections for the right hemisphere for BrdU immunodetection and analysis).

\section{Cerebrovascular reactivity}

Isolated and pressurized PCA segments $(n=4-5$ mice/group for each experimental cohort) were used to test vasomotor function because they show similar impairments to middle cerebral artery segments (Tong et al., 2005; Zhang et al., 2013; Ongali et al., 2014; J.R., E.H., unpublished data not shown) and are more amenable due to lesser ramifications. Vessels were cannulated and pressurized $(60 \mathrm{mmHg})$ and dilations to acetylcholine (ACh, $10^{-10}$ to $10^{-5} \mathrm{M}$; Sigma-Aldrich), calcitonin generelated peptide (CGRP, $10^{-10}$ to $10^{-6} \mathrm{M}$; American Peptide), the transient potential vanilloid 4 (TRPV4) channel agonist GSK1016790A (GSK, $10^{-11}$ to $10^{-5} \mathrm{M}$; Sigma-Aldrich), and the KATP channel opener levchromakalim (LEV, $10^{-9}$ to $10^{-4} \mathrm{M}$; Tocris Bioscience) were measured after extraluminal application on vessels preconstricted with phenylephrine $\left(2 \times 10^{-7} \mathrm{M}\right.$; Sigma-Aldrich $)$ and online videomicroscopy, as described previously (Tong et al., 2005). Baseline production of nitric oxide (NO) was tested on vessels at resting tone by administration of the NO synthase (NOS) inhibitor $\mathrm{N}^{\omega}$-nitro-L-arginine (L-NNA, $10^{-5} \mathrm{M}$, 40 min; Sigma-Aldrich).

\section{Western blots}

Proteins from brain samples and blood vessels ( $n=4-5$ mice/group) were extracted as described previously (Tong et al., 2005). Membranes were incubated ( $1 \mathrm{~h}$, room temperature) in TBS-Tween blocking buffer (50 mmol/L NaCl, $0.1 \%$ Tween 20 , containing $7 \%$ skim milk) and incubated overnight $\left(4^{\circ} \mathrm{C}\right)$ with either of the following primary antibodies: mouse anti-AT1R (1:200; Frei et al., 2001) mouse anti-angiotensin II type 2 receptor (1:200, AT2R; Frei et al., 2001), rabbit anti-AT4R (insulin regulated aminopeptidase, IRAP, 1:500; Cell Signaling Technology), and rabbit anti-superoxide dismutase-2 (SOD2, 1:3000; Stressgen). Membranes were further incubated for $1 \mathrm{~h}$ using horseradish peroxidase-conjugated species-specific secondary antibodies (1:2000; Jackson ImmunoResearch). Gradient gels $(8-20 \%)$ were used to separate $A \beta$ monomers and oligomers and incubated overnight in anti- $\beta$ amyloid 1-16 antibody (1:1000; 6E10; Covance; Wiltfang et al., 1997). Actin (mouse anti- $\beta$-actin; 1:10,000; Sigma-Aldrich) was used to standardize loading (Tong et al., 2005).

\section{Histochemical staining, immunohistochemistry,} and immunofluorescence

$A \beta$ plaques. Mature dense core $\mathrm{A} \beta$ plaques were stained with thioflavin $\mathrm{S}$ $(1 \%, 8 \mathrm{~min})$. Diffuse and mature plaques were stained by overnight incubation with $6 \mathrm{E} 10$ antibody (1:800) followed by either goat antimouse cyanin 2 (Cy2)-conjugated secondary antibody (1:400, $30 \mathrm{~min}$ ) or biotinylated IgG (Vector Laboratories, $1 \mathrm{~h} 30 \mathrm{~min}$ ), avidin-biotin complex (Vector Laboratories, $1 \mathrm{~h} 15 \mathrm{~min}$ ), and visualized with 3, 3'-diaminobenzidine-nickel solution (Vector Laboratories).

Inflammation and oxidative stress. Activated astrocytes and microglial cells, used as markers of neuroinflammation, were detected by overnight immunostaining with, respectively, rabbit anti-glial fibrillary acidic protein (GFAP, 1:1000; DAKO), or anti-ionized calcium binding adaptor molecule 1 (Iba-1, 1:300; Wako Pure Chemical Industries). Staining was visualized with a goat anti-rabbit Cy2-conjugated secondary antibody (1:400, $30 \mathrm{~min}$ ). Mitochondrial SOD2 protein was immunodetected after overnight incubation with rabbit anti-SOD2 (1:400; Stressgen), followed by the SG reagent (gray blue precipitate; Vector Laboratories).

Neurogenesis. Newborn cells were identified in the dentate gyrus of the hippocampus in free floating $40-\mu \mathrm{m}$-thick sections incubated in $50 \%$ $0.03 \mathrm{~m}$ saline-sodium citrate and $50 \%$ formamide solution $\left(2 \mathrm{~h}, 65^{\circ} \mathrm{C}\right)$, washed with $0.03 \mathrm{M}$ saline-sodium citrate buffer $(2 \mathrm{~min})$, and incubated in $\mathrm{HCl}\left(2 \mathrm{M}, 30 \mathrm{~min}, 37^{\circ} \mathrm{C}\right)$ to open the DNA structure. Subsequently, sections were rinsed in borate buffer $(0.1 \mathrm{M}, 10 \mathrm{~min})$, washed in $0.1 \mathrm{M}$ PBS (15 min), and incubated in rat anti-BrdU (1:400, overnight; Boehringer Mannheim), followed by immunodetection with Cy2 goat anti-rat secondary antibody (30 min, Vector Laboratories; Duveau et al., 2011).

\section{Statistical analysis}

Blood pressure measures, MWM, LDF, and vascular reactivity experiments were performed blinded to the identity of the mice. Vascular responses were expressed as the percentage change in vessel diameter as a function of agonist concentration or duration of NOS inhibition. The agonist dose-response curves were generated with GraphPad Prism (version 6) software and analyzed by repeated-measures ANOVA. The average maximal agonist response $\left(\mathrm{EA}_{\max }\right)$ and affinity $\left[\mathrm{pD}_{2}\right.$, value $=-(\log$ $\left.\mathrm{EC}_{50}\right)$ ] were calculated using GraphPad Prism software. Western blot membranes were developed and quantified using enhanced chemilumi- 
nescence (ECL; LI-COR) with a Chemiluminescent Western Blot Scanner (C-DiGit; Li-COR) or ECL (Plus kit; GE Healthcare) with a phosphor imager (scanner STORM 860; GE Health Care). For anatomical studies, sections were mounted on gelatin-coated slides, coverslipped, and observed under light (SOD2 and 6E10) or fluorescence (thioflavin S, GFAP, Iba-1, 6E10, and BrdU) microscopy using a Leitz Aristoplan microscope equipped with epifluorescence (FITC filter). Low-power digital images in the delineated areas of interest at selected bregma levels (Lein et al., 2007; A $\beta$ plaques: cingulate, and hippocampus; GFAP and Iba-1: somatosensory cortex; BrdU: dentate gyrus of the hippocampus) were analyzed (2-3 sections/mouse, $n=4-5$ mice/group) using MetaMorph version $6.1 \mathrm{r} 3$ software (Universal Imaging). The surface area occupied by thioflavin $\mathrm{S}$ - and $\mathrm{A} \beta$-positive plaques (bregma levels -1.46 to -1.70 $\mathrm{mm}$ ), as well as by GFAP-positive (bregma levels -1.70 to $-1.82 \mathrm{~mm}$ ), Iba-1-positive (bregma levels -1.46 to $-1.70 \mathrm{~mm}$ ), and SOD2-positive (bregma levels 0.02 to $-0.10 \mathrm{~mm}$ ) elements was quantified. For neurogenesis, BrdU-immunopositive nuclei of newborn cells (bregma levels -1.94 to $-2.18 \mathrm{~mm}$ ) were counted directly under the microscope. Data were analyzed by either one- or two-way ANOVA (with genotype and treatment as factors), followed by Newman-Keuls multiple-comparisons tests, and are expressed as mean \pm SEM (GraphPad Prism 6). $p \leq$ 0.05 was considered significant. Both cohorts yielded similar results.

\section{Results}

Cognitive benefits of losartan are reversed by AT4R blockade In both cohorts, APP mice had significantly longer escape latencies in MWM1 compared with WT controls (Fig. 1A). APP mice that underwent 3 months of losartan treatment were not significantly better than nontreated APP mice at spatial learning, as shown here for cohort 1 (Fig. 1A). Losartan-treated APP mice did, however, display significantly improved memory retrieval in the probe trial compared with untreated APP mice for all parameters including percentage distance traveled and time spent in the target quadrant and number of platform crossings (Fig. $1 B-D$ ). Losartan had no effect on memory performance in WT mice compared with WT controls (Fig. 1A-E). Despite a slightly slower, albeit significant, swimming speed difference for APP controls during the probe trial, we proceeded with 1 month of concomitant divalinal intervention to investigate the role of the AngIV/ AT4R cascade.

MWM2 was performed during the fourth week of divalinal administration. Spatial learning and memory retrieval were significantly impaired in untreated 7-month-old APP mice compared with WT counterparts, as shown by their significantly higher escape latencies to the hidden platform (Fig. $1 F$ ) and parameters measured in the probe trial (Fig. $1 G-J$ ). In contrast, losartan-treated APP mice had a steep learning curve and performed as well as WT controls on days 4 and 5 of spatial learning (Fig. $1 F$ ) and for all parameters measured in the probe trial for memory retrieval (Fig. 1G-I). Divalinal countered losartanmediated benefits on spatial learning (Fig. $1 F$ ) and memory (Fig. $1 G-I)$, with losartan + divalinal-treated APP mice performing as poorly as untreated APP mice. No treatment condition altered performance of WT mice (Fig. $1 F-J)$. Swimming speeds were comparable in all groups, except between losartan + divalinaltreated WT and APP mice (Fig. 1J, cohort 1 only).

Memory impairment in $\mathrm{AD}$ mouse models has been associated with reduced hippocampal neurogenesis (Haughey et al., 2002; Zhang et al., 2007; Ermini et al., 2008). Accordingly, neurogenesis detected by BrdU labeling of newborn cells in the dentate gyrus was significantly reduced in APP mice compared with WT controls (Fig. $1 K, L$ ). Losartan slightly increased neurogenesis in treated APP mice, bringing the number of positive BrdU cells to intermediary levels not significantly different from either WT or APP mice (Fig. $1 K, L$ ). This enhancing effect of losartan was abrogated in losartan + divalinal-treated APP mice, which, like APP mice, displayed significantly fewer BrdU-positive cells in the dentate gyrus compared with WT controls (Fig. $1 K, L$ ). Interestingly, losartan + vehicle and losartan + divalinal treatments exerted similar nonsignificant enhancing and reducing effects on neurogenesis in WT mice (Fig. $1 K, L)$.

\section{AT4R blockade counters the cerebrovascular benefits of losartan in APP mice}

Losartan treatment fully rescued the impaired vasodilation to ACh and CGRP (Fig. 2A,B) and recovered the reduced baseline NO bioavailability depicted by the decreased contractile response to NOS inhibition in untreated APP compared with WT cerebral blood vessels (Fig. 2C). Divalinal coadministration either completely or significantly counteracted losartan's benefits on dilatory function and $\mathrm{NO}$ bioavailability because vessels from losartan + divalinal-treated APP mice responded as poorly as untreated APP mice (Fig. $2 A-C$ ). We further investigated the effects of treatments on TRPV4 and KATP channels that contribute, respectively, to ACh-mediated (Zhang et al., 2013) and CGRP-mediated vasodilations (Kitazono et al., 1993; Tong et al., 2009), and are impaired in APP mice. We found that losartan completely normalized dilatory responses mediated by both channels, with responses comparable to those of WT controls (Fig. 2D,E). Concomitant divalinal administration significantly counteracted losartan's benefits on TRPV4, but not KATP, channels (Fig. $2 D, E$ ). Receptor desensitization did not account for any of the vasodilatory alterations and decreased EA $_{\text {max }}$ because agonist affinities were comparable across genotype and treatment conditions for all vasoactive compounds tested (Table 2).

Whisker-evoked neurovascular coupling responses were impaired in APP mice compared with WT controls (Fig. $2 F$ ), as reported previously (Tong et al., 2009; Tong et al., 2012; Ongali et al., 2014). In losartan-treated APP mice, evoked CBF responses were not significantly different from either APP or WT mice (Fig. $2 F$ ). In contrast, losartan + divalinal-treated APP mice responded as poorly as untreated APP mice and evoked CBF responses were significantly lower than WT controls (Fig. $2 F$ ), suggesting that part of the losartan-enhancing effect was sensitive to divalinal.

\section{Losartan or divalinal administration does not alter A $\boldsymbol{\beta}$ pathology}

Cortical and hippocampal plaque load in APP mice, as measured by both thioflavin S-positive dense core plaques (Fig. $3 A, B$ ) and 6 E10-immunopositive mature and diffuse $\mathrm{A} \beta$ plaques (Fig. $3 C, D$ ), were comparable in all groups whether untreated or treated with losartan or losartan + divalinal. Losartan, however, slightly increased APP protein levels in hippocampus $(p<0.05$; Fig. $3 F)$ and pial vessels $(p<0.01$, Fig. $3 G)$, whereas the small increase in the cerebral cortex was not significant (Fig. $3 E$ ). This effect of losartan was significantly reduced by coadministration of divalinal in pial vessels, but not in hippocampus (Fig. $3 G, F$ ). For all groups of APP mice, there was no difference in the $56 \mathrm{kDa}$ oligomeric species (Fig. $3 E-G$ ), an A $\beta$ species previously correlated with cognitive deficit in AD mice (Lesné et al., 2006). Similarly, $\mathrm{A} \beta$ dimers ( $9 \mathrm{kDa} \mathrm{A} \beta$ species) involved in disruption of hippocampal LTP and memory impairment in adult rodents (Walsh et al., 2002; Klyubin et al., 2005; Freir et al., 2011), were not significantly different across treatment conditions in the hippocampus (Fig. 3F). Cortical and pial $9 \mathrm{kDa} A \beta$ species were undetectable in 7-month-old APP mice, as re- 

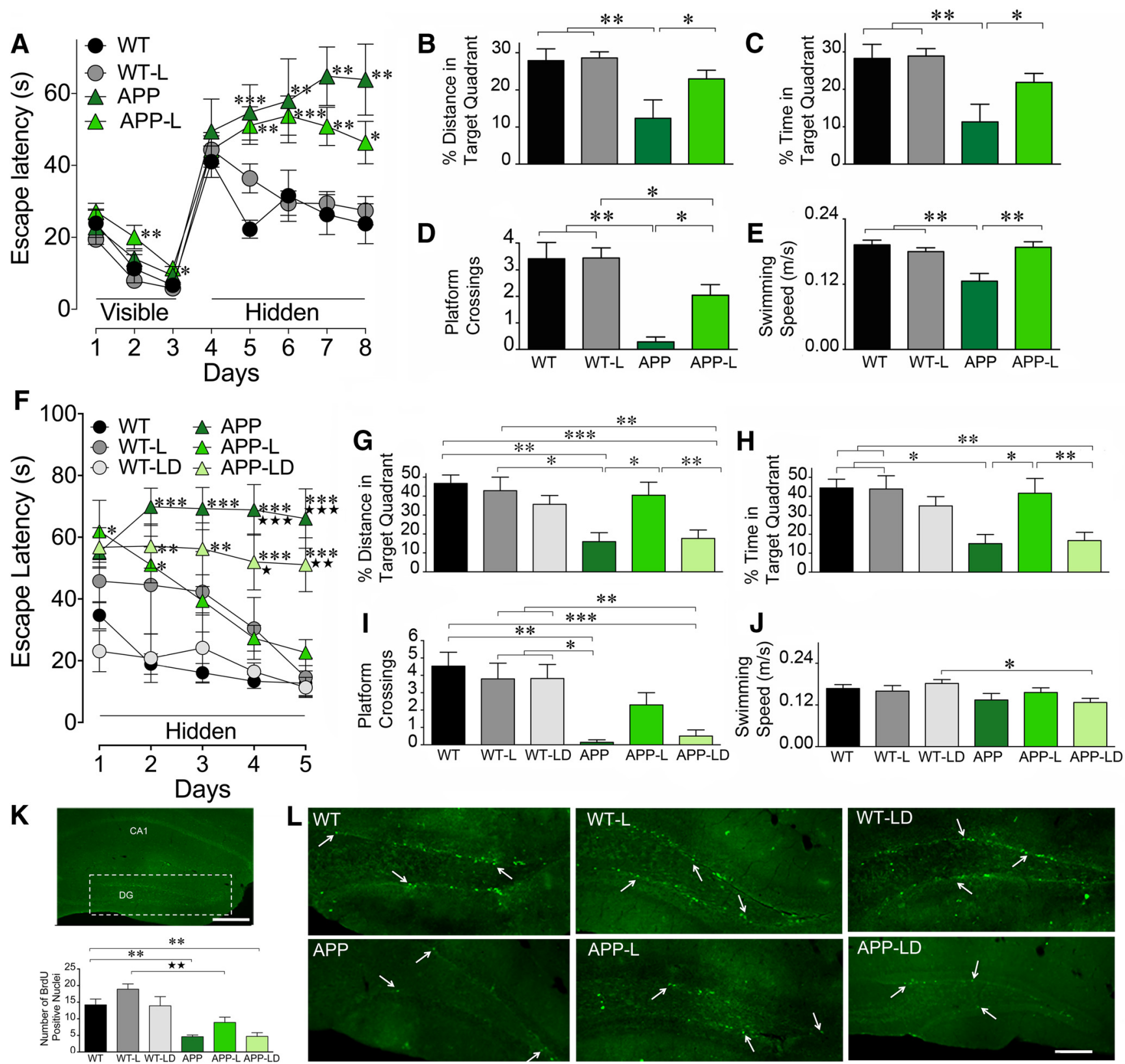

Figure 1. AT4Rantagonism countered the beneficial effects of losartan on cognitive performance in adult APP mice. Three months after losartan (L) therapy, APP mice $(n=23)$ had similar escape latencies $(\boldsymbol{A})$ to untreated APP mice $(n=21)$ in the hidden platform training. L-treated APP mice, however, performed as well as WT controls $(n=10)$ in the probe trial $(\boldsymbol{B}-\boldsymbol{D})$ and were significantly different from APP controls. L treatment had no effect on WT mice $(n=21)$. Despite a significant difference in swimming speed for untreated APP mice $(\boldsymbol{E})$, treatment continued. After 1 month of combined intervention, L-treated APP mice $(n=10)$ displayed similar escape latencies $(\boldsymbol{F})$ to WT mice $(n=10)$ in the hidden platform training, whereas APP mice treated with L-divalinal (LD, $n=$ 12) were as impaired as untreated APP mice $(\boldsymbol{F}, n=10)$. In the second probe, L-treated APP mice performed as well as WT controls and were significantly different from untreated APP mice and LD-treated APP mice $(\mathbf{G}-\boldsymbol{I})$. No difference was observed in speed across APP mice; however, a slight difference was present between WT and LD-treated APP mice $(\boldsymbol{J})$. Combined LD treatment had no effect on WT mice $(n=11)$. Immunopositive newborn cells (BrdU-positive nuclei, arrows) in the dentate gyrus (DG) of the hippocampus were significantly reduced in untreated APP mice compared with WT $(\boldsymbol{K}, \boldsymbol{L})$. L treatment slightly elevated the number of newborn cells in treated APP mice, a benefit that was reduced after LD administration $(\boldsymbol{K}, \boldsymbol{L})$. Comparisons with WT mice are indicated with ${ }^{*} p<0.05,{ }^{* *} p<0.01$, and ${ }^{* *} p<0.001$ and with L-treated APP mice with $\star p<0.05$, $\star p<0.01$, and $\star \star \star p<0.001$. Scale bar in $K: 500$ and $150 \mu \mathrm{m} . n=4-5$ mice/group.

ported previouslyin APP mice of a similar age (Tong et al., 2012).

\section{AT4R blockade counters losartan's benefits on inflammation} but not oxidative stress

Astroglial and microglial cells were significantly activated in the cortex of APP mice compared with WT controls, as evidenced by increased GFAP and Iba-1 immunofluorescence surface area (Fig. 4). Losartan significantly reduced this inflammatory response in APP mice and divalinal coadministration reduced these benefits (Fig. 4). Cortical and hippocampal SOD2, a mitochondrial antioxidant enzyme upregulated in conditions of increased free radicals (Lindenau et al., 2000; Tong et al., 2005), was significantly increased in APP mice compared with WT controls (Fig. $5 A, B)$. Losartan reduced this response to levels not significantly different from WT mice and divalinal did not revert this antioxidant property of losartan (Fig. $5 A, B$ ). In pial vessels, SOD2 protein levels were similarly affected in APP mice and by losartan or combined losartan + divalinal treatment, but these effects did not reach significance (Fig. 5C). 

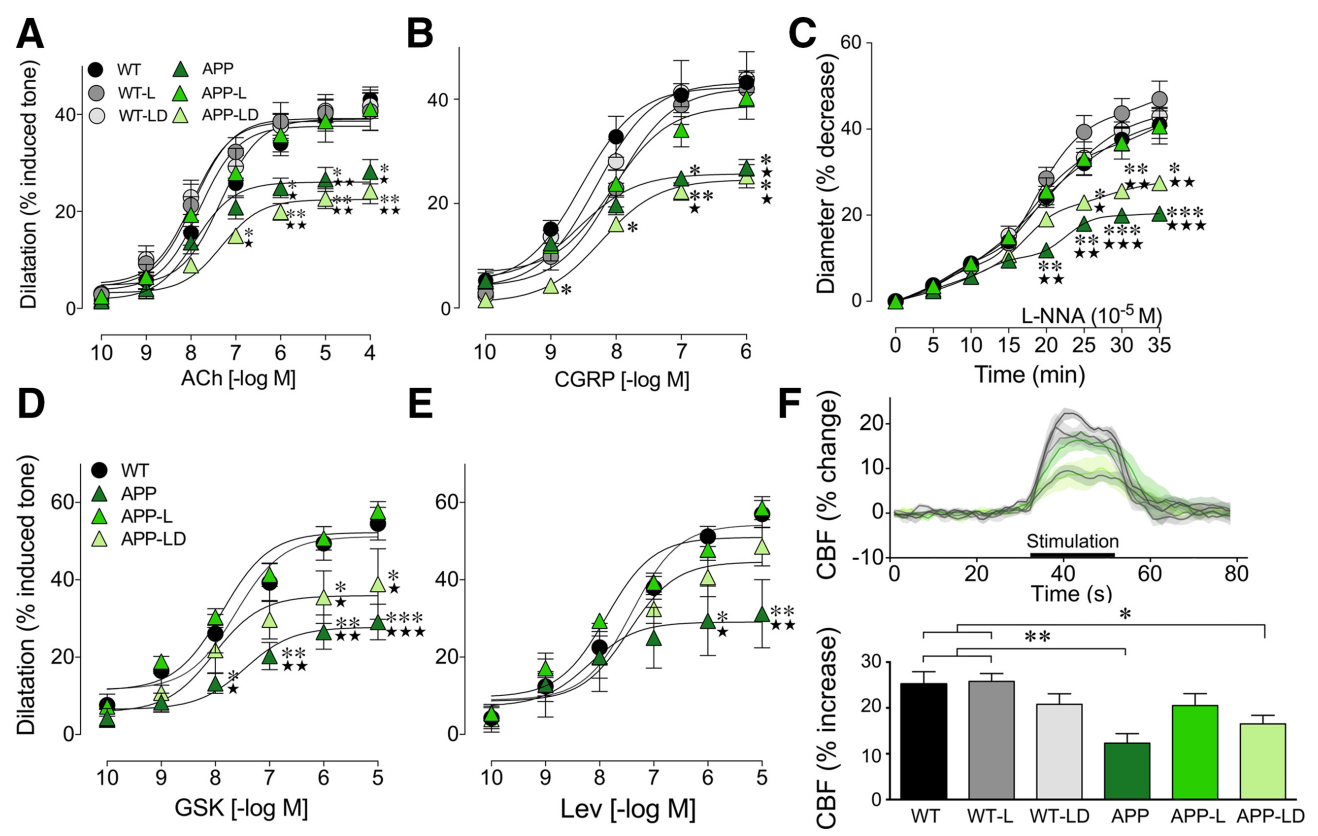

Figure 2. AT4R blockade countered losartan's beneficial effects on cerebrovascular reactivity and neurovascular coupling in APP mice. Losartan (L) treatment rescued the impaired dilatory responses to ACh and CGRP of isolated arterial segments from APP mice, responses in L-treated APP mice being comparable to those of WT mice $(A, B)$. These benefits were countered by divalinal (D) coadministration, as shown in LD-APP mice compared with L-APP mice $(\boldsymbol{A}, \boldsymbol{B})$. Similarly, the reduced baseline production of N0 in APP mice compared with WT controls, measured by blocking NOS activity with L-NNA, was normalized in L-treated APP mice ( $C$. LD treatment significantly counteracted these benefits, with vessels from LD-treated APP mice responding as poorly as untreated APP mice (C). In addition, TRPV4 and KATP channel-mediated vasodilatory responses measured, respectively, with GSK and LEV, were normalized in L-APP mice compared with untreated APP mice $(\boldsymbol{D}, \boldsymbol{E})$. Concurrent LD treatment in APP mice prevented the benefit on TRPV4 channels seen in L-treated APP mice, but had no effect on KATP channel-mediated vasodilatory responses $(\boldsymbol{D}, \boldsymbol{E})$. $n=$ 4-6 mice/group ( $\boldsymbol{A}-\boldsymbol{E})$. LDF was used to measure neurovascular coupling responses, expressed as the maximal whisker-evoked CBF increase from baseline. Untreated and LD-treated APP mice had significantly impaired evoked increases in CBF compared with WT controls. L-treated APP mice were not significantly different from WT or APP controls $(\boldsymbol{F}) . n=5-7$ mice/group $(\boldsymbol{F})$. Error bars indicate SEM. Comparisons with WT are indicated by ${ }^{*} p<0.05,{ }^{* *} p<0.01$, and ${ }^{* * *} p<0.001$ and with APP L-treated APP mice by $\star p<0.05, \star \star p<0.01$, and $\star \star \star p<0.001$. Data were analyzed using either one- or two-way ANOVA followed by Newman-Keuls post hoc multiple-comparisons tests.

Table 2. Effects of losartan and divalinal on cerebrovascular responses in WT and APP mice

\begin{tabular}{|c|c|c|c|c|c|c|}
\hline & WT & WT-L & WT-LD & APP & APP-L & APP-LD \\
\hline \multicolumn{7}{|l|}{$\mathrm{ACh}$} \\
\hline$E A_{\max }$ & $43.0 \pm 2.0$ & $40.6 \pm 3.9$ & $41.8 \pm 2.6$ & $28.2 \pm 2.5^{*} \star$ & $41.1 \pm 4.5$ & $24.1 \pm 2.5^{* *} \star \star$ \\
\hline $\mathrm{pD}_{2}$ & $7.3 \pm 0.1$ & $7.9 \pm 0.2$ & $8.0 \pm 0.2$ & $7.9 \pm 0.2$ & $7.8 \pm 0.2$ & $7.3 \pm 0.2$ \\
\hline \multicolumn{7}{|l|}{ CGRP } \\
\hline$E A_{\max }$ & $43.2 \pm 1.9$ & $42.0 \pm 3.5$ & $43.8 \pm 5.3$ & $26.9 \pm 1.6^{*} \star$ & $40.3 \pm 4.1$ & $25.2 \pm 2.2^{*} \star$ \\
\hline $\mathrm{pD}_{2}$ & $8.5 \pm 0.1$ & $8.0 \pm 0.2$ & $8.3 \pm 0.3$ & $8.6 \pm 0.2$ & $8.1 \pm 0.2$ & $8.2 \pm 0.1$ \\
\hline \multicolumn{7}{|l|}{ GSK } \\
\hline$E A_{\max }$ & $51.2 \pm 3.0$ & NA & NA & $27.7 \pm 2.5^{*} \star$ & $52.2 \pm 2.0$ & $35.9 \pm 1.8$ \\
\hline $\mathrm{pD}_{2}$ & $7.6 \pm 0.2$ & & & $7.5 \pm 0.4$ & $7.9 \pm 0.2$ & $8.0 \pm 0.2$ \\
\hline \multicolumn{7}{|l|}{ LEV } \\
\hline$E A_{\max }$ & $54.2 \pm 2.7$ & NA & NA & $29.1 \pm 3.9^{* *} \star \star$ & $51.0 \pm 2.1$ & $44.6 \pm 2.3$ \\
\hline $\mathrm{pD}_{2}$ & $7.4 \pm 0.2$ & & & $8.2 \pm 0.6$ & $7.9 \pm 0.2$ & $7.5 \pm 0.2$ \\
\hline \multicolumn{7}{|l|}{ L-NNA } \\
\hline$E A_{\max }$ & $59.0 \pm 3.2$ & $53.1 \pm 4.2$ & $57.1 \pm 2.1$ & $79.6 \pm 0.8^{* * *} \star \star \star \star$ & $59.3 \pm 4.1$ & $72.6 \pm 1.1^{*} \star \star$ \\
\hline
\end{tabular}

Data are mean $\pm \operatorname{SEM}\left(n=4-6\right.$ mice per group) and are expressed as the $\mathrm{EA}_{\max }$ or $\mathrm{pD}_{2}$. EA $\max$ is the percentage maximal dilation of ACh, CGRP, GSK, and LEV and the percentage maximal decrease after 35 min of NOS inhibition with $10^{-5} \mathrm{ML}$ L-NNA.

${ }^{*} \star p<0.05 ;{ }^{* *} \star \star p<0.01,{ }^{* * *} \star \star \star p<0.001$ compared with WT control mice ${ }^{*}$ ) or APP-losartan-treated mice $(\star)$ using one-way ANOVA followed by Newman-Keuls post hoc multiple-comparisons tests.

L, Losartan; LD, L-divalinal; NA, not applicable.

\section{Losartan or divalinal administration does not alter angiotensin receptor expression}

No differences were observed for cortical and hippocampal AT1R protein levels across all groups despite a trend toward an elevation in losartan-treated APP mice and a reduction to WT control levels in losartan + divalinal-treated APP mice (Fig. 6A,B). Similar trends were observed in the hippocampus of WT mice (Fig. $6 A, B)$. AT2Rs were comparable in the cortex and hippocampus for all groups (Fig. $6 C, D$ ). AT4Rs, although similar in the cortex across treatments and genotypes, were slightly, albeit not signif- icantly, elevated in the hippocampus in losartan-treated groups and divalinal tended to prevent this elevation (Fig. $6 E, F$ ).

\section{Discussion}

The present study demonstrates that divalinal potently blocked losartan's benefits on spatial learning and memory, neuroinflammation, dilatory function, and NO bioavailability in the vessel wall and had a modest effect on functional hyperemia. Knowing the selectivity, stability, and efficacious specificity of divalinal's antagonism for AT4Rs (Krebs et al., 1996), our results identify a 
A

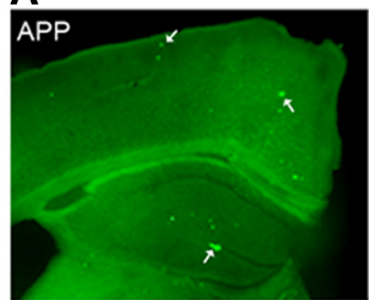

C
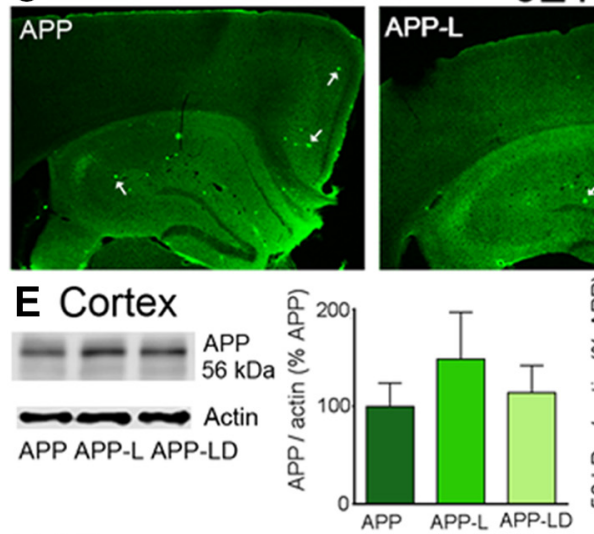

F Hippocampus
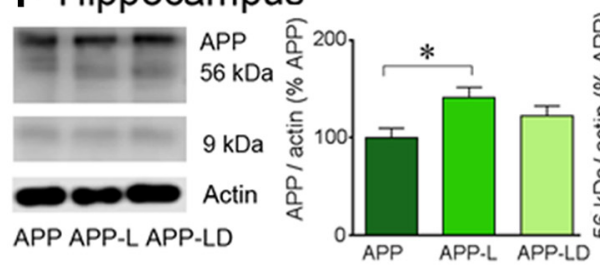

APP APP-L APP-LD
Thioflavin S

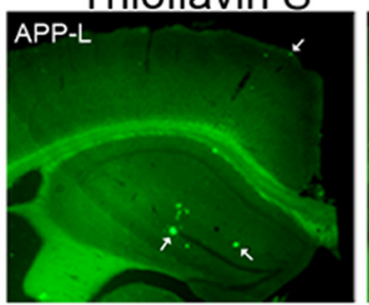

6E10
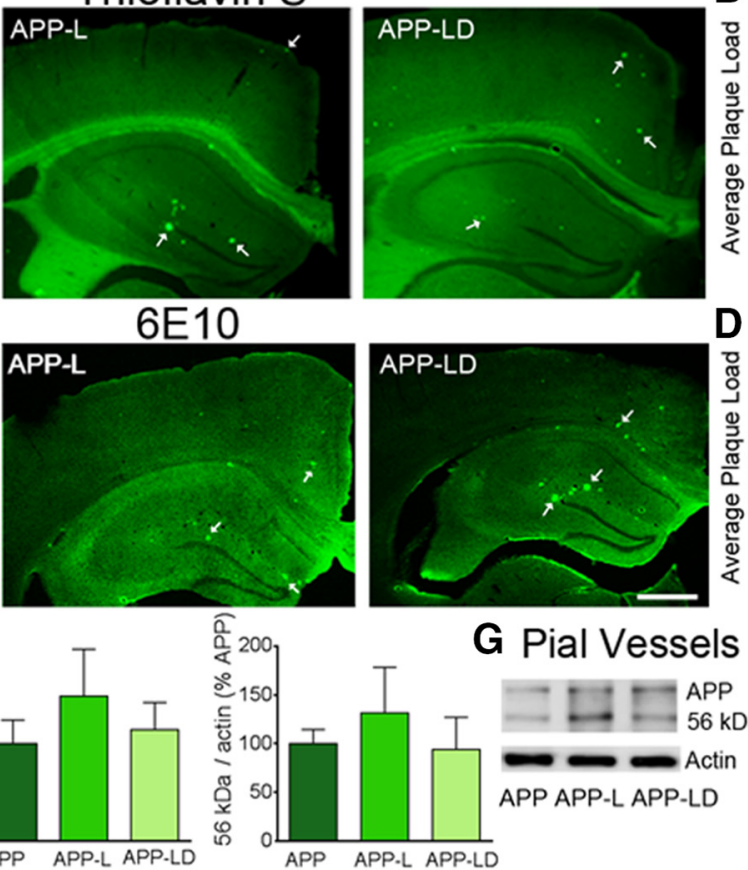
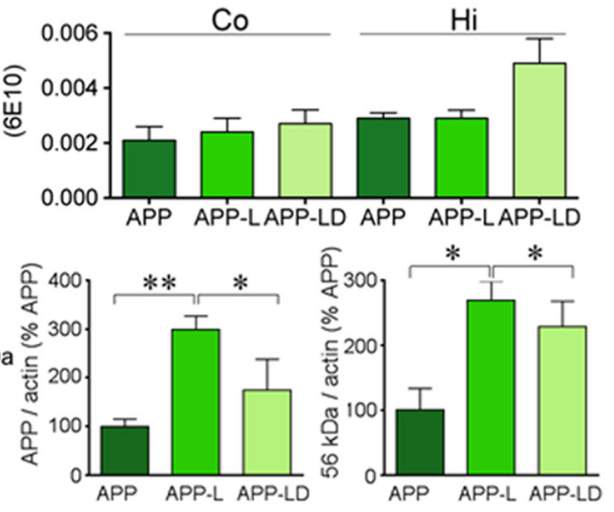
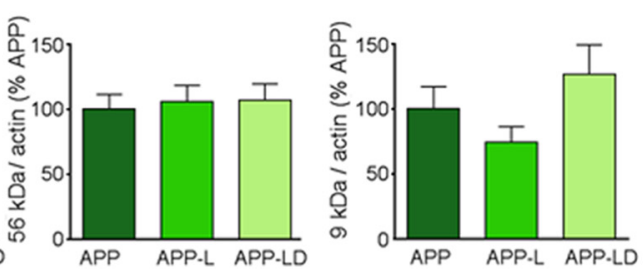

Figure 3. Amyloid pathology in APP mice: effects of losartan and combined losartan + divalinal treatments. Cortical and hippocampal surface area occupied by dense core (thioflavin $S$ staining; $\boldsymbol{A}, \boldsymbol{B}$ ) or total A $\beta$ (6E10 immunofluorescence; $\boldsymbol{C}, \boldsymbol{D})$ plaques in APP mice were not altered after losartan (L) or losartan + divalinal (LD) treatment. Cortical A $\beta$ was not significantly altered across treatment conditions $(\boldsymbol{E})$. Compared with untreated APP mice, those treated with L had increased levels of APP $(100 \mathrm{kDa})$ in pial vessels $(\boldsymbol{G})$ and hippocampus $(\boldsymbol{F})$. Pial vessels also displayed increased levels of the soluble $56 \mathrm{kDa}$ oligomeric species after $\mathrm{L}$ and $\mathrm{LD}$ treatments $(\boldsymbol{G})$. Actin was used to normalize loading variation. $n=4-5$ mice/group. Significance is indicated by ${ }^{*} p<0.05$ and ${ }^{* *} p<0.01$. Data were analyzed using one-way ANOVA followed by Newman-Keuls post hoc multiple-comparisons tests. Error bars indicate SEM. Scale bars, $500 \mu m$.

role for the AngIV/AT4R cascade in the neuronal and cerebrovascular benefits of losartan in APP mice. Our results further demonstrate that the centrally acting and commonly prescribed ARB losartan exerts blood-pressure-independent neuroprotective effects, which should be considered separately from the recognized ability of high blood pressure (hypertension) to increase the risk of AD. Therefore, our findings have significance, not only for hypertensive prodromal $\mathrm{AD}$ and $\mathrm{AD}$ patients, but also for nonhypertensive AD patients in identifying AT4Rs as a new target for therapeutic intervention. We conclude that the benefits of losartan result mainly from its pleiotropic ability to promote endothelial function and reduce neuroinflammation through the AngIV/AT4R cascade.

\section{Cognitive function and memory-related pathways}

Whereas our results agree with prior studies that reported neuroprotective benefits after sartan therapy in transgenic APP (Wang et al., 2007; Ongali et al., 2014) or A $\beta_{1-40}$-injected mice (Mogi et al., 2008; Takeda et al., 2009), they are the first to provide an underlying mechanism of action. Most importantly, they concur with a recent quantitative meta-analysis (Zhuang et al., 2016) that clearly demonstrated associations between ARB use and reduced incidence of $\mathrm{AD}$, as well as a decreased risk of developing cognitive impairment. Divalinal's ability to counter losartanmediated memory recovery in APP mice establishes a role for the
AngIV/AT4R cascade in mediating these benefits. Such a conclusion is supported by previous reports documenting AngIVmediated improved memory performance (Braszko et al., 1988; Wright et al., 1999; Tchekalarova et al., 2001), as well as deficits in spatial memory in AT4R knock-out mice (Albiston et al., 2010). Enhanced cognitive function by AT4Rs is thought to occur through facilitated synaptic transmission and LTP in hippocampal CA1 (Kramár et al., 2001) and dentate gyrus (Wayner et al., 2001). Incidentally, the hippocampus is particularly rich in AT4Rs (Wright et al., 1993) and hippocampal neurogenesis plays an essential role in learning and memory (Deng et al., 2010). When searching for a possible role of losartan on memory recovery, we confirmed a reduced neurogenesis in our APP model, as in other AD transgenic mice (Hamilton et al., 2010; Gonzalez-Castaneda et al., 2011; Martinez-Canabal, 2014). In contrast, we found a number of newborn cells in the dentate gyrus of losartan-treated APP mice comparable to that of WT controls, a response abrogated by divalinal. These enhancing and counteracting effects, however, did not reach significance toward untreated APP mice. We thus conclude that, although positive in $\mathrm{AD}$ patients with diminished synaptic connectivity and increased neuronal death, restoring neurogenesis is unlikely the primary mechanism through which losartan rescues memory in APP mice. 
A
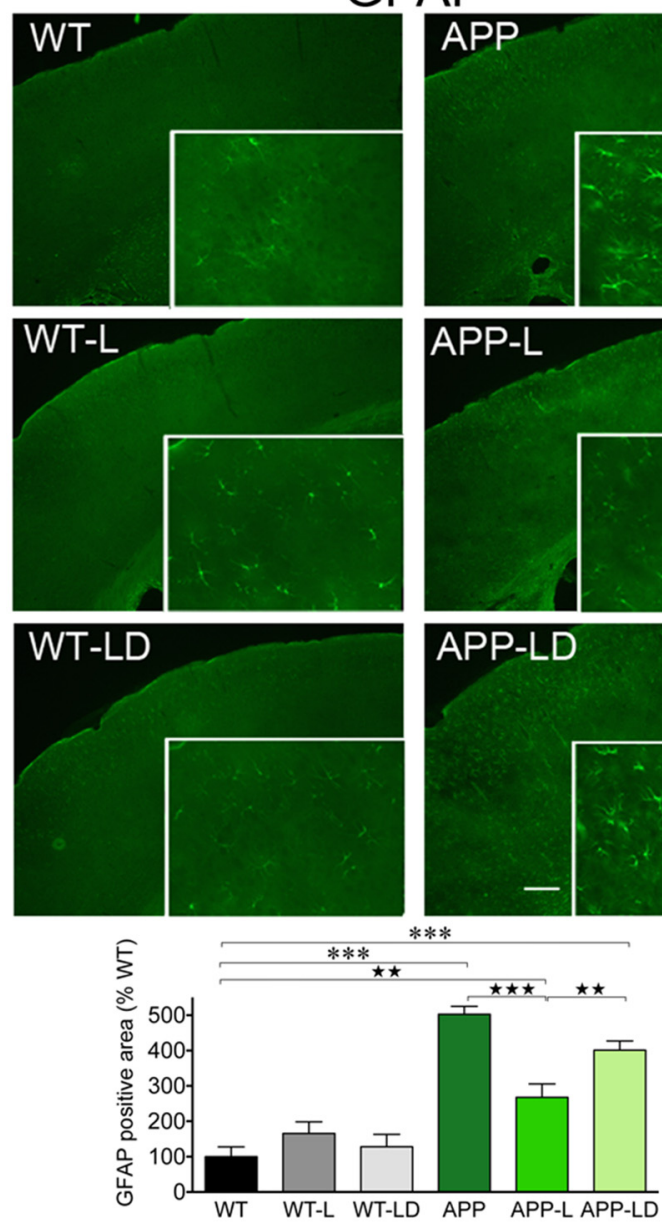

B
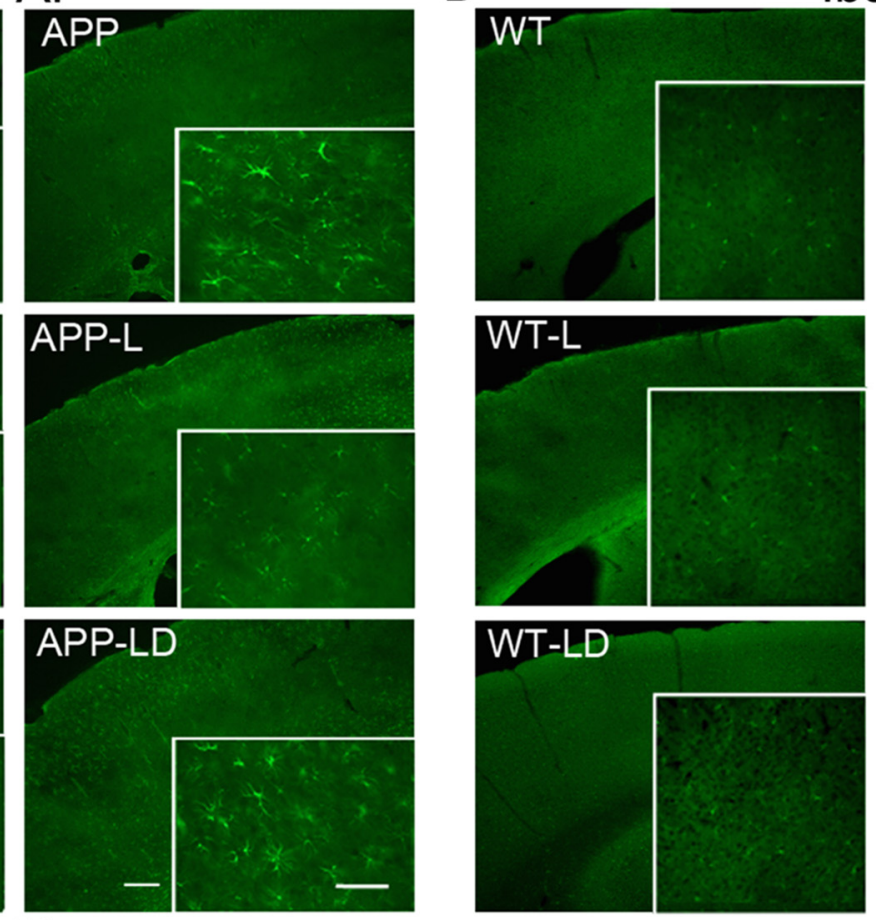

lba-1
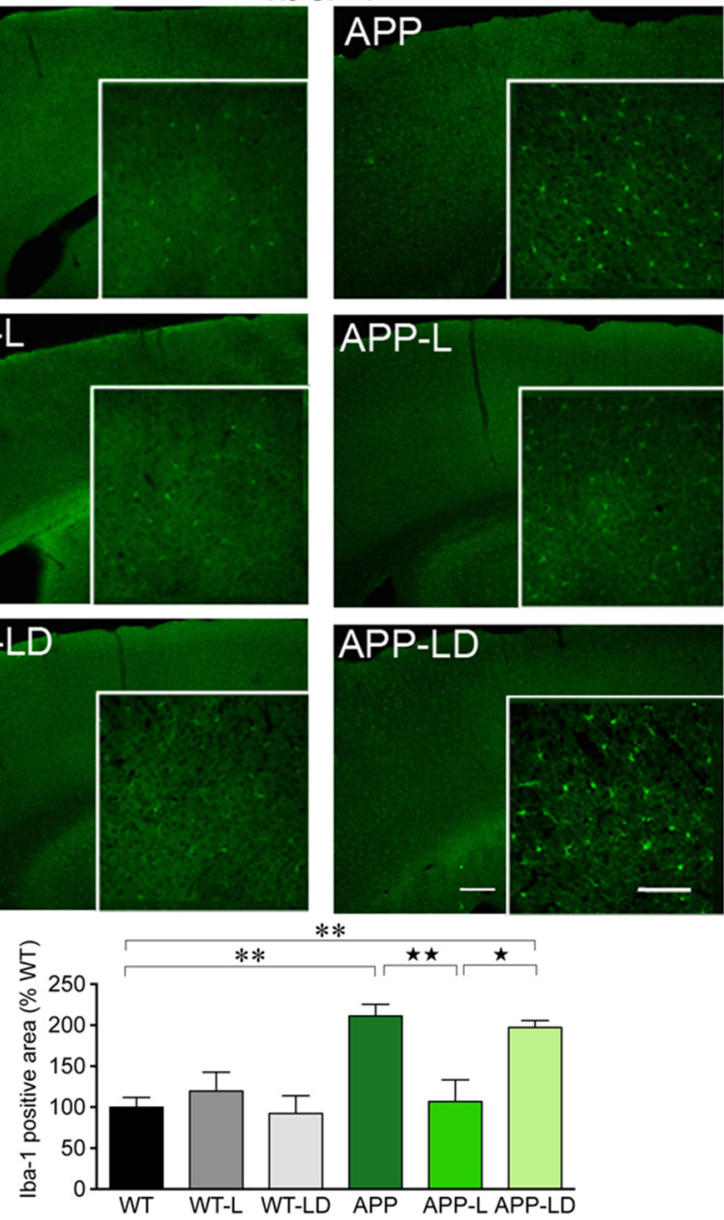

Figure 4. Divalinal reduced losartan's benefits on astrogliosis and microgliosis in APP mice. The surface area occupied by GFAP-immunostained astrocytes was significantly increased in the cortex of APP mice relative to WT $(\boldsymbol{A})$. Losartan (L) significantly reduced this inflammatory response, a benefit partly but significantly reversed by combined losartan + divalinal (LD) treatment $(\boldsymbol{A})$. Similarly, Iba-1-immunopositive microglial cells were elevated in APP mice compared with WT and reduced after $L$ treatment $(\boldsymbol{B})$, a response almost abolished by $D(B)$. Results were analyzed by two-way ANOVA followed by Newman-Keuls post hoc test. Comparisons with WT are indicated by ${ }^{* *} p<0.01$ and ${ }^{* * *} p<0.001$ and with APP L-treated mice by $\star p<0.05, \star \star p<0.01$, and $\star \star \star p<0.001 . n=4-5$ mice/group. Error bars indicate SEM. Scale bars, 0.5 and $500 \mu \mathrm{m}$.

\section{No effect of amyloid pathology but changes in APP protein levels}

We found no reducing effects of losartan on $A \beta$ pathology, confirming that cognitive rescue can be achieved regardless of reducing soluble $\mathrm{A} \beta$ species and $\mathrm{A} \beta$ plaque load (Cheng et al., 2007; Ferrington et al., 2012; Tong et al., 2012). These findings agree with previous reports in transgenic APP (Ongali et al., 2014) and $\mathrm{A} \beta_{1-40}$-injected (Mogi et al., 2008) mice, but differ from those with other ARBs in APP/PS1 transgenic mice (Danielyan et al., 2010) and in $\mathrm{A} \beta_{1-40}$-injected mice (Takeda et al., 2009). Our results thus exclude a role for AT4Rs on the amyloid pathology and agree with clinical trials using active $\mathrm{A} \beta_{1-42}$ immunization, in which patients deteriorated cognitively despite plaque clearance (Holmes et al., 2008). An unexpected finding in our study was losartan-mediated increases in APP protein levels in cortex, hippocampus, and pial vessels. Prior studies have suggested that synaptotoxicity depends on changes in $\mathrm{A} \beta$ and are independent of human APP levels (Mucke et al., 2000); therefore, the perceived changes in APP protein levels may not contribute to synaptic dysregulation. Because APP-containing synapses within the hippocampus and frontal cortex have been correlated with the protein's role in mediating neuronal growth, memory, and synaptic plasticity (Huber et al., 1997; Turner et al., 2003), we cannot exclude that losartan exerted beneficial effects on neurons or synapses by upregulating brain levels of APP. AT4Rs may not exclusively mediate these effects because divalinal blockade was significant only in pial vessels. Interestingly, in the brain vasculature, although a role for APP still needs to be better defined (Katusic et al., 2016), interactions between basal endothelial NO and APP processing have been identified (Austin et al., 2010). Our results show that these pathways are both sensitive to losartan through the AngIV/AT4R cascade.

\section{Cerebrovascular reactivity and oxidative stress}

The most important finding in the cerebrovascular investigation was divalinal's ability to abolish losartan's benefits on dilatory function. Particularly, its abrogating effects on dilations to ACh support a role for AT4Rs in endothelial-dependent vasodilation of brain vessels (Haberl et al., 1991). ACh-mediated dilations occur primarily through endothelial m5 muscarinic ACh receptor-mediated NO release (Elhusseiny et al., 2000; Yamada et al., 2001) and TRPV4 channel activation via intermediate and small conductance $\mathrm{Ca}^{2+}$-sensitive $\mathrm{K}^{+}$channel activation (Zhang et al., 2013). Because divalinal blocks losartan's rescue of these two responses, our results identify pathways in which the AngIV/ AT4R cascade restores endothelial function. Divalinal also coun- 


\section{A Cortex}
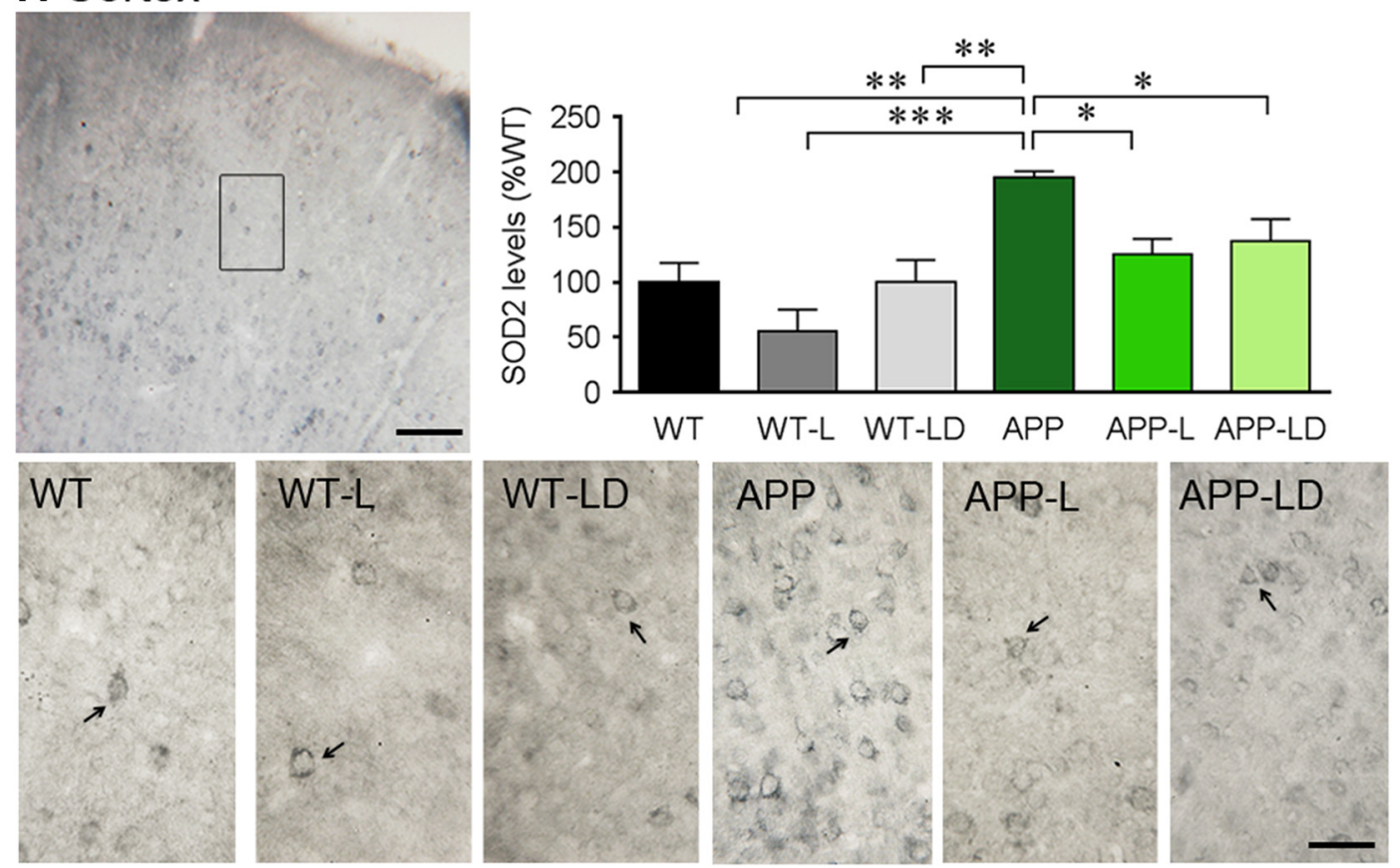

\section{B Hippocampus}

\section{Pial}
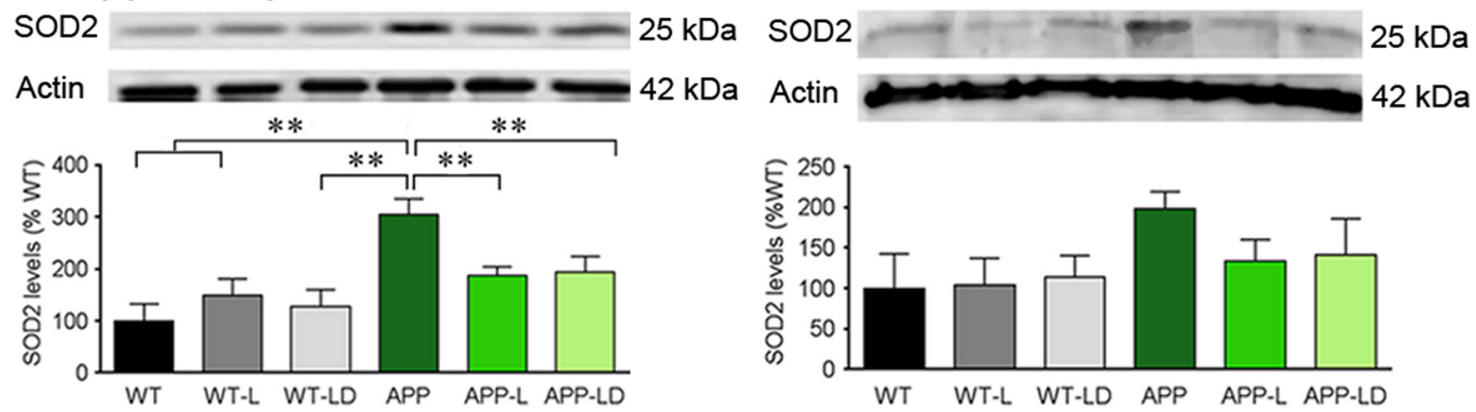

Figure 5. AT4R blockade did not affect the antioxidant benefits of losartan. Cortical SOD2 immunoreactivity was significantly increased in APP mice compared with WT mice (A), a response returned to WT levels by losartan $(L)$ treatment and not affected by concomitant losartan + divalinal (LD) treatment $(\boldsymbol{A})$. Similarly, coadministration of $L D$ did not counter $L$ 's reversal of the upregulated SOD2 protein levels measured by Western blot in the hippocampus of APP mice (B). A similar trend for pial vessel SOD2 protein levels was observed after LD treatments, but this was not significant ( $\boldsymbol{C}$. Actin was used to standardize loading variation. Results were analyzed by two-way ANOVA followed by Newman-Keuls posthoctest. Significance is indicated by ${ }^{*} p<0.05$, ${ }^{* *} p<0.01$, and ${ }^{* * *} p<0.001$. Data were analyzed using two-way ANOVA followed by Newman-Keuls post hoc multiple-comparisons tests. $n=4-5$ mice/group. Error bars indicate SEM. Scale bar, $150 \mu \mathrm{m}$.

\section{Cortex}
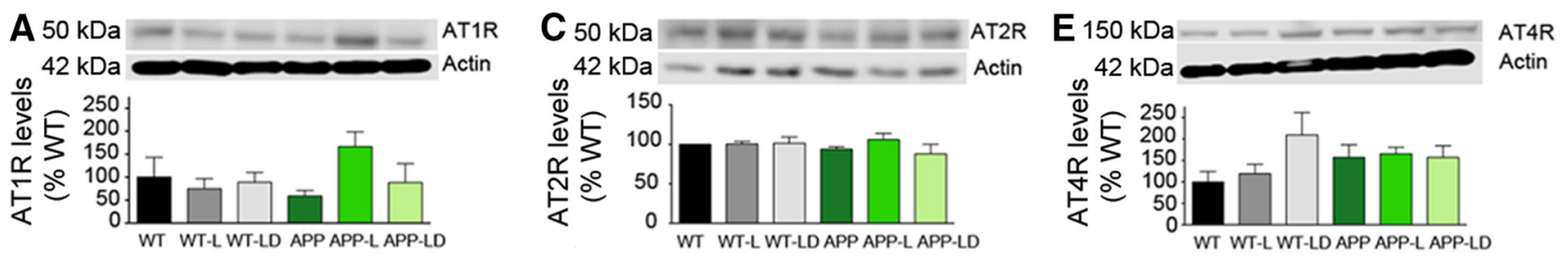

\section{Hippocampus}
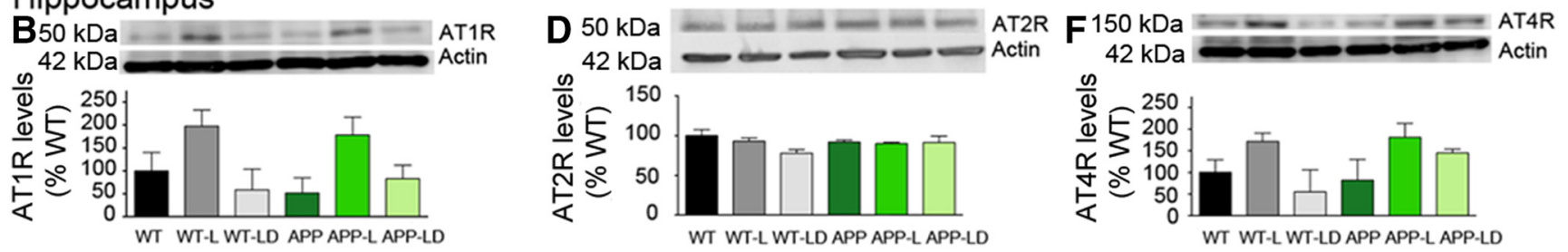

Figure 6. AT1Rs, AT2Rs, and AT4Rs in the brain: effects of losartan and combined losartan + divalinal treatments. No significant difference was observed across individual conditions for AT1R, AT2R, and AT4R protein levels in either the cortex or hippocampus after post hoc comparisons $(\boldsymbol{A}-\boldsymbol{F})$. Results were analyzed by two-way ANOVA followed by Newman-Keuls post hoc test. $n=4-5$ mice/group. L, Losartan; LD, combined losartan + divalinal treatment. Error bars indicate SEM. 
tered losartan's benefit on CGRP-mediated dilations that involve smooth muscle KATP channels (Kitazono et al., 1993; Tong et al., 2009) and $\mathrm{Ca}^{2+}$ activated $\mathrm{K}^{+}$channels (Vedernikov et al., 2002), but not on KATP channel-mediated dilations, suggesting that these channels are not involved in AT4R-mediated normalization of CGPR dilations. The impaired baseline NO production or bioavailability in APP mouse blood vessels, which has been imputed to sequestration of NO by reactive oxygen species (ROS) (Iadecola et al., 1999; Hamel et al., 2016), was restored by losartan in a divalinal-sensitive manner, supporting a role for the AngIV/ AT4R cascade in facilitating NO synthesis and release from brain endothelial cells (Kramár et al., 1998). We found that divalinal did not prevent the antioxidant benefits of losartan on brain or cerebrovascular SOD2 protein levels, suggesting that losartan acts via other pathways than the AngIV/AT4R cascade, such as the p47phox (Zhu et al., 2007) or p67phox (Ongali et al., 2014) subunit of the ROS-generating enzyme NADPH oxidase.

\section{Neuroinflammation and neurovascular coupling}

Mitochondrial dysfunction and neuroinflammation are deleterious mechanisms that contribute to neuronal and vascular dysfunctions in AD patients (McGeer et al., 2003; Grammas, 2011; Morales et al., 2014) and APP mice (Lacoste et al., 2013; Ongali et al., 2014). Divalinal significantly, albeit not completely, prevented losartan's anti-inflammatory properties on GFAP and Iba-1 levels in cortical astrocytes and microglia, implying a role for AT4Rs on losartan benefits. Other studies have supported a role for AngIV in maintaining or salvaging the structural and functional integrity of astrocytes, such as restoring astrocyte adhesion, growth, and morphology (Kakinuma, 1998). Knowing that neurovascular coupling relies on tight interactions among neurons, astrocytes, and the microvasculature (Mishra, 2017) and that AngIV can increase CBF via activation of divalinalsensitive AT4Rs (Kramár et al., 1997), the partial blockade by divalinal of losartan-induced positive effects on whisker-evoked CBF responses may be attributed to its inability to fully antagonize losartan's benefits on astrogliosis. The counteracting effects of divalinal on the reduced microglial activation afforded by losartan provide an additional means for the AngIV/AT4R cascade in reducing neurotoxic molecules (Klegeris et al., 2000). Indeed, both mitochondrial dysfunction and neuroinflammation can increase oxidative stress through excessive release of ROS and reactive nitrogen species, thus promoting neuronal damage and potentiating neuroinflammation (de la Monte et al., 2006; Morales et al., 2014; Bhat et al., 2015). The benefits of the AngIV/ AT4R cascade may be attributed to inhibition of this positive feedback loop of neuroinflammation, thus preventing the initiation of excessive microglial and astrocytic activation and reducing toxicity within the brain parenchyma.

\section{Angiotensin receptor subtypes}

Seven-month-old APP mice did not show altered levels of AT1Rs compared with WT, a finding contrary to that in older APP mice (Ongali et al., 2014), suggesting that receptor alterations may relate to disease progression. Similarly, AT4Rs were not altered in young APP mice, but losartan tended to upregulate them in the hippocampus, as found in older mice (Ongali et al., 2014), a response slightly mitigated by divalinal. No changes were present in cortical or hippocampal AT2Rs across treatments, supporting the idea that the benefits were independent of AT2Rs. Together, these results suggest that AT4R function rather than levels is defective in young APP mice.

\section{Conclusion}

Our results indicate that the AngIV/AT4R cascade mediates the cognitive and cerebrovascular benefits observed in APP mice treated with the ARB losartan. They provide strong arguments for a mechanism of action for the reported decreased incidence of $\mathrm{AD}$ in hypertensive patients treated by ARBs. Because AD is multifactorial, the pleiotropic actions of losartan via the AngIV/ AT4R cascade demonstrated here at both neuronal and cerebrovascular levels should be considered a promising therapeutic target in $\mathrm{AD}$. For these reasons, preclinical and clinical studies should investigate the efficacy of AngIV analogs for the prevention and treatment of $\mathrm{AD}$.

\section{References}

Akioyamen L, Levine M, Sherifali D, O'Reilly D, Frankfurter C, Pullenayegum E, Goeree R, Tsoi B (2016) Cardiovascular and cerebrovascular outcomes of long-term angiotensin receptor blockade: metaanalyses of trials in essential hypertension. J Am Soc Hypertens 10:55-69.e1. CrossRef Medline

Albiston AL, Fernando RN, Yeatman HR, Burns P, Ng L, Daswani D, Diwakarla S, Pham V, Chai SY (2010) Gene knockout of insulin-regulated aminopeptidase: loss of the specific binding site for angiotensin IV and age-related deficit in spatial memory. Neurobiol Learn Mem 93:19-30. CrossRef Medline

Austin SA, Santhanam AV, Katusic ZS (2010) Endothelial nitric oxide modulates expression and processing of amyloid precursor protein. Circ Res 107:1498-1502. CrossRef Medline

Ayata C, Shin HK, Salomone S, Ozdemir-Gursoy Y, Boas DA, Dunn AK, Moskowitz MA (2004) Pronounced hypoperfusion during spreading depression in mouse cortex. J Cereb Blood Flow Metab 24:1172-1182. Medline

Bhat AH, Dar KB, Anees S, Zargar MA, Masood A, Sofi MA, Ganie SA (2015) Oxidative stress, mitochondrial dysfunction and neurodegenerative diseases; a mechanistic insight. Biomed Pharmacother 74:101-110. CrossRef Medline

Braszko JJ, Kupryszewski G, Witczuk B, Wiśniewski K (1988) Angiotensin II-(3-8)-hexapeptide affects motor activity, performance of passive avoidance and a conditioned avoidance response in rats. Neuroscience 27:777-783. CrossRef Medline

Braszko JJ, Walesiuk A, Wielgat P (2006) Cognitive effects attributed to angiotensin II may result from its conversion to angiotensin IV. J Renin Angiotensin Aldosterone Syst 7:168-174. CrossRef Medline

Cheng IH, Scearce-Levie K, Legleiter J, Palop JJ, Gerstein H, Bien-Ly N, Puoliväli J, Lesné S, Ashe KH, Muchowski PJ, Mucke L (2007) Accelerating amyloid-beta fibrillization reduces oligomer levels and functional deficits in Alzheimer disease mouse models. J Biol Chem 282:23818 23828. CrossRef Medline

Danielyan L, Klein R, Hanson LR, Buadze M, Schwab M, Gleiter CH, Frey WH (2010) Protective effects of intranasal losartan in the APP/PS1 transgenic mouse model of Alzheimer disease. Rejuvenation Res 13:195201. CrossRef Medline

de la Monte SM, Wands JR (2006) Molecular indices of oxidative stress and mitochondrial dysfunction occur early and often progress with severity of Alzheimer's disease. J Alzheimers Dis 9:167-181. CrossRef Medline

Deipolyi AR, Fang S, Palop JJ, Yu GQ, Wang X, Mucke L (2008) Altered navigational strategy use and visuospatial deficits in hAPP transgenic mice. Neurobiol Aging 29:253-266. CrossRef Medline

Deng W, Aimone JB, Gage FH (2010) New neurons and new memories: how does adult hippocampal neurogenesis affect learning and memory? Nat Rev Neurosci 11:339-350. CrossRef Medline

Duchemin S, Belanger E, Wu R, Ferland G, Girouard H (2013) Chronic perfusion of angiotensin II causes cognitive dysfunctions and anxiety in mice. Physiol Behav 109:63-68. CrossRef Medline

Duveau V, Laustela S, Barth L, Gianolini F, Vogt KE, Keist R, Chandra D, Homanics GE, Rudolph U, Fritschy JM (2011) Spatiotemporal specificity of GABAA receptor-mediated regulation of adult hippocampal neurogenesis. Eur J Neurosci 34:362-373. CrossRef Medline

Elhusseiny A, Hamel E (2000) Muscarinic-but not nicotinic-acetylcholine receptors mediate a nitric oxide-dependent dilation in brain cortical arterioles: a possible role for the M5 receptor subtype. J Cereb Blood Flow Metab 20:298-305. Medline 
Ermini FV, Grathwohl S, Radde R, Yamaguchi M, Staufenbiel M, Palmer TD, Jucker M (2008) Neurogenesis and alterations of neural stem cells in mouse models of cerebral amyloidosis. Am J Pathol 172:1520-1528. CrossRef Medline

Ferrington L, Palmer LE, Love S, Horsburgh KJ, Kelly PA, Kehoe PG (2012) Angiotensin II-inhibition: effect on Alzheimer's pathology in the aged triple transgenic mouse. Am J Transl Res 4:151-164. Medline

Frei N, Weissenberger J, Beck-Sickinger AG, Höfliger M, Weis J, Imboden H (2001) Immunocytochemical localization of angiotensin II receptor subtypes and angiotensin II with monoclonal antibodies in the rat adrenal gland. Regul Pept 101:149-155. CrossRef Medline

Freir DB, Fedriani R, Scully D, Smith IM, Selkoe DJ, Walsh DM, Regan CM (2011) $\mathrm{A} \beta$ oligomers inhibit synapse remodelling necessary for memory consolidation. Neurobiol Aging 32:2211-2218. CrossRef Medline

Ganten D, Marquez-Julio A, Granger P, Hayduk K, Karsunky KP, Boucher R, Genest J (1971) Renin in dog brain. Am J Physiol 221:1733-1737. Medline

Girouard H, Iadecola C (2006) Neurovascular coupling in the normal brain and in hypertension, stroke, and Alzheimer disease. J Appl Physiol (1985) 100:328-335.

Gonzalez-Castaneda RE, Galvez-Contreras AY, Luquín S, Gonzalez-Perez O (2011) Neurogenesis in Alzheimer's disease: a realistic alternative to neuronal degeneration? Curr Signal Transduct Ther 6:314-319. CrossRef Medline

Gorelick PB et al. (2011) Vascular contributions to cognitive impairment and dementia: a statement for healthcare professionals from the american heart association/american stroke association. Stroke 42:2672-2713. CrossRef Medline

Grammas P (2011) Neurovascular dysfunction, inflammation and endothelial activation: implications for the pathogenesis of Alzheimer's disease. J Neuroinflammation 8:26. CrossRef Medline

Haberl RL, Decker PJ, Einhäupl KM (1991) Angiotensin degradation products mediate endothelium-dependent dilation of rabbit brain arterioles. Circ Res 68:1621-1627. CrossRef Medline

Hamel E, Royea J, Ongali B, Tong XK (2016) Neurovascular and cognitive failure in Alzheimer's disease: benefits of cardiovascular therapy. Cell Mol Neurobiol 36:219-232. CrossRef Medline

Hamilton LK, Aumont A, Julien C, Vadnais A, Calon F, Fernandes KJ (2010) Widespread deficits in adult neurogenesis precede plaque and tangle formation in the $3 \times \mathrm{Tg}$ mouse model of Alzheimer's disease. Eur J Neurosci 32:905-920. CrossRef Medline

Hardy J, Selkoe DJ (2002) The amyloid hypothesis of Alzheimer's disease: progress and problems on the road to therapeutics. Science 297:353-356. CrossRef Medline

Haughey NJ, Liu D, Nath A, Borchard AC, Mattson MP (2002) Disruption of neurogenesis in the subventricular zone of adult mice, and in human cortical neuronal precursor cells in culture, by amyloid beta-peptide: implications for the pathogenesis of Alzheimer's disease. Neuromolecular Med 1:125-135. CrossRef Medline

Holmes C, Boche D, Wilkinson D, Yadegarfar G, Hopkins V, Bayer A, Jones RW, Bullock R, Love S, Neal JW, Zotova E, Nicoll JA (2008) Long-term effects of Abeta42 immunisation in Alzheimer's disease: follow-up of a randomised, placebo-controlled phase I trial. Lancet 372:216-223. CrossRef Medline

Huber G, Bailly Y, Martin JR, Mariani J, Brugg B (1997) Synaptic betaamyloid precursor proteins increase with learning capacity in rats. Neuroscience 80:313-320. CrossRef Medline

Iadecola C, Zhang F, Niwa K, Eckman C, Turner SK, Fischer E, Younkin S, Borchelt DR, Hsiao KK, Carlson GA (1999) SOD1 rescues cerebral endothelial dysfunction in mice overexpressing amyloid precursor protein. Nat Neurosci 2:157-161. CrossRef Medline

Iturria-Medina Y, Sotero RC, Toussaint PJ, Mateos-Pérez JM, Evans AC, Alzheimer's Disease Neuroimaging I (2016) Early role of vascular dysregulation on late-onset Alzheimer's disease based on multifactorial datadriven analysis. Nat Commun 7:11934. CrossRef Medline

Kakinuma Y, Hama H, Sugiyama F, Yagami K, Goto K, Murakami K, Fukamizu A (1998) Impaired blood-brain barrier function in angiotensinogen-deficient mice. Nat Med 4:1078-1080. CrossRef Medline

Katusic ZS, Austin SA (2016) Neurovascular protective function of endothelial nitric oxide-recent advances. Circ J 80:1499-1503. CrossRef Medline

Kehoe PG, Wong S, Al Mulhim N, Palmer LE, Miners JS (2016)
Angiotensin-converting enzyme 2 is reduced in Alzheimer's disease in association with increasing amyloid-beta and tau pathology. Alzheimers Res Ther 8:50. CrossRef Medline

Khachaturian AS, Zandi PP, Lyketsos CG, Hayden KM, Skoog I, Norton MC, Tschanz JT, Mayer LS, Welsh-Bohmer KA, Breitner JC (2006) Antihypertensive medication use and incident Alzheimer disease: the Cache County study. Arch Neurol 63:686-692. CrossRef Medline

Kitazono T, Heistad DD, Faraci FM (1993) Role of ATP-sensitive K+ channels in CGRP-induced dilatation of basilar artery in vivo. Am J Physiol 265:H581-H585. Medline

Klegeris A, McGeer PL (2000) Interaction of various intracellular signaling mechanisms involved in mononuclear phagocyte toxicity toward neuronal cells. J Leukocyte Biol 67:127-133. Medline

Klyubin I, Walsh DM, Lemere CA, Cullen WK, Shankar GM, Betts V, Spooner ET, Jiang L, Anwyl R, Selkoe DJ, Rowan MJ (2005) Amyloid beta protein immunotherapy neutralizes Abeta oligomers that disrupt synaptic plasticity in vivo. Nat Med 11:556-561. CrossRef Medline

Kramár EA, Harding JW, Wright JW (1997) Angiotensin II- and IVinduced changes in cerebral blood flow: roles of AT1, AT2, and AT4 receptor subtypes. Regul Pept 68:131-138. CrossRef Medline

Kramár EA, Krishnan R, Harding JW, Wright JW (1998) Role of nitric oxide in angiotensin IV-induced increases in cerebral blood flow. Regul Pept 74:185-192. CrossRef Medline

Kramár EA, Armstrong DL, Ikeda S, Wayner MJ, Harding JW, Wright JW (2001) The effects of angiotensin IV analogs on long-term potentiation within the CA1 region of the hippocampus in vitro. Brain Res 897:114121. CrossRef Medline

Krebs LT, Kramár EA, Hanesworth JM, Sardinia MF, Ball AE, Wright JW, Harding JW (1996) Characterization of the binding properties and physiological action of divalinal-angiotensin IV, a putative AT4 receptor antagonist. Regul Pept 67:123-130. CrossRef Medline

Lacoste B, Tong XK, Lahjouji K, Couture R, Hamel E (2013) Cognitive and cerebrovascular improvements following kinin B 1 receptor blockade in Alzheimer's disease mice. J Neuroinflammation 10:57. CrossRef Medline

Lein ES, et al. (2007) Genome-wide atlas of gene expression in the adult mouse brain. Nature 445:168-176. CrossRef Medline

Lesné S, Koh MT, Kotilinek L, Kayed R, Glabe CG, Yang A, Gallagher M, Ashe $\mathrm{KH}$ (2006) A specific amyloid-b protein assembly in the brain impairs memory. Nature 440:352-357. CrossRef Medline

Lindenau J, Noack H, Possel H, Asayama K, Wolf G (2000) Cellular distribution of superoxide dismutases in the rat CNS. Glia 29:25-34. CrossRef Medline

Magavi SS, Leavitt BR, Macklis JD (2000) Induction of neurogenesis in the neocortex of adult mice. Nature 405:951-955. CrossRef Medline

Martinez-Canabal A (2014) Reconsidering hippocampal neurogenesis in Alzheimer's disease. Front Neurosci 8:147. CrossRef Medline

McGeer EG, McGeer PL (2003) Inflammatory processes in Alzheimer's disease. Prog Neuropsychopharmacol Biol Psychiatry 27:741-749. CrossRef Medline

Mishra A (2017) Binaural blood flow control by astrocytes: listening to synapses and the vasculature. J Physiol 595:1885-1902. CrossRef Medline

Mogi M, Horiuchi M (2009) Effects of angiotensin II receptor blockers on dementia. Hypertens Res 32:738-740. CrossRef Medline

Mogi M, Li JM, Tsukuda K, Iwanami J, Min LJ, Sakata A, Fujita T, Iwai M, Horiuchi M (2008) Telmisartan prevented cognitive decline partly due to PPAR-gamma activation. Biochem Biophys Res Commun 375:446449. CrossRef Medline

Morales I, Guzmán-Martínez L, Cerda-Troncoso C, Farías GA, Maccioni RB (2014) Neuroinflammation in the pathogenesis of Alzheimer's disease: a rational framework for the search of novel therapeutic approaches. Front Cell Neurosci 8:112. CrossRef Medline

Mucke L, Masliah E, Yu GQ, Mallory M, Rockenstein EM, Tatsuno G, Hu K, Kholodenko D, Johnson-Wood K, McConlogue L (2000) High-level neuronal expression of abeta 1-42 in wild-type human amyloid protein precursor transgenic mice: synaptotoxicity without plaque formation. J Neurosci 20:4050-4058. Medline

Ongali B, Nicolakakis N, Tong XK, Aboulkassim T, Papadopoulos P, RosaNeto P, Lecrux C, Imboden H, Hamel E (2014) Angiotensin II type 1 receptor blocker losartan prevents and rescues cerebrovascular, neuropathological and cognitive deficits in an Alzheimer's disease model. Neurobiol Dis 68:126-136. CrossRef Medline

Reitz C, Tang MX, Manly J, Mayeux R, Luchsinger JA (2007) Hypertension 
and the risk of mild cognitive impairment. Arch Neurol 64:1734-1740. CrossRef Medline

Savaskan E, Hock C, Olivieri G, Bruttel S, Rosenberg C, Hulette C, MüllerSpahn F (2001) Cortical alterations of angiotensin converting enzyme, angiotensin II and AT1 receptor in Alzheimer's dementia. Neurobiol Aging 22:541-546. CrossRef Medline

Serrano-Pozo A, Frosch MP, Masliah E, Hyman BT (2011) Neuropathological alterations in Alzheimer disease. Cold Spring Harb Perspect Med 1:a006189. CrossRef Medline

Shibasaki Y, Mori Y, Tsutumi Y, Masaki H, Sakamoto K, Murasawa S, Maruyama K, Moriguchi Y, Tanaka Y, Iwasaka T, Inada M, Matsubara H (1999) Differential kinetics of circulating angiotensin IV and II after treatment with angiotensin II type 1 receptor antagonist and their plasma levels in patients with chronic renal failure. Clin Nephrol 51:83-91. Medline

Takeda S, Sato N, Takeuchi D, Kurinami H, Shinohara M, Niisato K, Kano M, Ogihara T, Rakugi H, Morishita R (2009) Angiotensin receptor blocker prevented beta-amyloid-induced cognitive impairment associated with recovery of neurovascular coupling. Hypertension 54:1345-1352. CrossRef Medline

Tchekalarova J, Kambourova T, Georgiev V (2001) Interaction between angiotensin IV and adenosine $\mathrm{A}(1)$ receptor related drugs in passive avoidance conditioning in rats. Behav Brain Res 123:113-116. CrossRef Medline

Tong XK, Nicolakakis N, Kocharyan A, Hamel E (2005) Vascular remodeling versus amyloid beta-induced oxidative stress in the cerebrovascular dysfunctions associated with Alzheimer's disease. J Neurosci 25:1116511174. CrossRef Medline

Tong XK, Nicolakakis N, Fernandes P, Ongali B, Brouillette J, Quirion R, Hamel E (2009) Simvastatin improves cerebrovascular function and counters soluble amyloid-beta, inflammation and oxidative stress in aged APP mice. Neurobiol Dis 35:406-414. CrossRef Medline

Tong XK, Lecrux C, Rosa-Neto P, Hamel E (2012) Age-dependent rescue by simvastatin of Alzheimer's disease cerebrovascular and memory deficits. J Neurosci 32:4705-4715. CrossRef Medline

Turner PR, O'Connor K, Tate WP, Abraham WC (2003) Roles of amyloid precursor protein and its fragments in regulating neural activity, plasticity and memory. Prog Neurobiol 70:1-32. CrossRef Medline

Vedernikov YP, Fulep EE, Saade GR, Garfield RE (2002) Calcitonin generelated peptide dilates the pregnant rat uterine vascular bed via guanylate cyclase, ATP- and Ca-sensitive potassium channels and gap junctions. Curr Med Res Opin 18:465-470. CrossRef Medline

Villapol S, Saavedra JM (2015) Neuroprotective effects of angiotensin receptor blockers. Am J Hypertens 28:289-299. CrossRef Medline

Walsh DM, Klyubin I, Fadeeva JV, Cullen WK, Anwyl R, Wolfe MS, Rowan MJ, Selkoe DJ (2002) Naturally secreted oligomers of amyloid b protein potently inhibit hippocampal long-term potentiation in vivo. Nature 416:535-539. CrossRef Medline

Wang J, Ho L, Chen L, Zhao Z, Zhao W, Qian X, Humala N, Seror I, Bartholomew S, Rosendorff C, Pasinetti GM (2007) Valsartan lowers brain beta-amyloid protein levels and improves spatial learning in a mouse model of Alzheimer disease. J Clin Invest 117:3393-3402. CrossRef Medline

Wayner MJ, Armstrong DL, Phelix CF, Wright JW, Harding JW (2001) Angiotensin IV enhances LTP in rat dentate gyrus in vivo. Peptides 22:14031414. CrossRef Medline

Wiltfang J, Smirnov A, Schnierstein B, Kelemen G, Matthies U, Klafki HW, Staufenbiel M, Hüther G, Rüther E, Kornhuber J (1997) Improved electrophoretic separation and immunoblotting of beta-amyloid (A beta) peptides 1-40,1-42, and 1-43. Electrophoresis 18:527-532. CrossRef Medline

Wright JW, Miller-Wing AV, Shaffer MJ, Higginson C, Wright DE, Hanesworth JM, Harding JW (1993) Angiotensin II(3-8; ANG IV) hippocampal binding: potential role in the facilitation of memory. Brain Res Bull 32:497-502. CrossRef Medline

Wright JW, Stubley L, Pederson ES, Kramár EA, Hanesworth JM, Harding JW (1999) Contributions of the brain angiotensin IV-AT4 receptor subtype system to spatial learning. J Neurosci 19:3952-3961. Medline

Yamada M, Lamping KG, Duttaroy A, Zhang W, Cui Y, Bymaster FP, McKinzie DL, Felder CC, Deng CX, Faraci FM, Wess J (2001) Cholinergic dilation of cerebral blood vessels is abolished in M(5) muscarinic acetylcholine receptor knockout mice. Proc Natl Acad Sci U S A 98:1409614101. CrossRef Medline

Zhang C, McNeil E, Dressler L, Siman R (2007) Long-lasting impairment in hippocampal neurogenesis associated with amyloid deposition in a knock-in mouse model of familial Alzheimer's disease. Exp Neurol 204: 77-87. CrossRef Medline

Zhang L, Papadopoulos P, Hamel E (2013) Endothelial TRPV4 channels mediate dilation of cerebral arteries: impairment and recovery in cerebrovascular pathologies related to Alzheimer's disease. Br J Pharmacol 170: 661-670. CrossRef Medline

Zhuang S, Li J, Wang X, Wang HF, Zhang WJ, Wang HY, Xing CM (2016) Renin-angiotensin system-targeting antihypertensive drugs and risk of vascular cognitive impairment: A meta-analysis. Neurosci Lett 615:1-8. CrossRef Medline

Zhu WW, Liu XP, Wu N, Zhao TT, Zhao Y, Zhang J, Shao JH (2007) Beneficial effects of losartan on vascular injury induced by advanced glycosylation end products and their receptors in spontaneous hypertension rats. Mol Cell Biochem 304:35-43. CrossRef Medline 